Radioactive waste

\section{British search for dumps opposed}

THE British search for radioactive waste disposal sites has run into trouble. Last October, the Nuclear Industry Radioactive Waste Executive (NIREX) flagged its intention to investigate two land sites as permanent dumps for contaminated material from the nuclear industry, classified as waste of low and intermediate activity. Now, Imperial Chemical Industries Limited (ICI), the owner of a disused anhydrite mine at Billingham in north-east England, says that it will oppose the plan to investigate that site, while local councillors say they have evidence that the second site, at Elstow in the Bedfordshire brickfields of central England, is unsuitable for its intended purpose.

ICl's anhydrite mine has been sealed for some years and the on-site investigations NIREX plans would probably require planning permission. ICI said this week that it does not intend applying for permission to open the mine, since it has no commercial interest and prefers to maintain good relations with the local community. A spokesman said it had become clear since October that local opinion is intensely hostile. When NIREX first announced its choice of the site as a possible permanent resting place for long-lived intermediate level wastes, it coyly did not mention that military wastes might also end up there. The outcry when that emerged some weeks later probably made NIREX wish it had been more forthright.

Even so, NIREX intends to press ahead with its Billingham plan without ICI's cooperation, although both sides admit that the legal position is far from clear. Because NIREX has no powers of compulsory purchase, it might have to face the rigours of a full public inquiry about Billingham armed only with the data it already has. ICI makes no bones of the fact that it would actively oppose NIREX at a public inquiry, on the grounds that good community relations are essential for the sake of its own business.

At Elstow, if the site proves suitable, NIREX plans to excavate a series of trenches in the local bed of Oxford clay to

take shorter-lived wastes. It has now become clear that the clay bed is only 15-20 metres thick, alt hough rather deeper layers were previously mentioned. The base of the clay layer is uneven and local hydrogeologists say there may be a fault on the site: there are certainly faults in the clay layer within $2 \mathrm{~km}$. There is also concern that nearby excavations where clay has been extracted in the past may make it impossible to predict groundwater flow with sufficient accuracy. NIREX will have to show that radionuclides will not within 200 or 300 years percolate through their encasing concrete blocks and enter the biosphere in significant amounts. Some of the nearby excavations are filled in with domestic refuse, again leading to uncertainty about patterns of groundwater flow.

A further complication is that the London Brick Company has permission to extract clay from the field immediately adjacent to the proposed site and has applied for planning permission to excavate the proposed dump site itself. There is little doubt the local authorities would agree to that request if it offered a way of keeping NIREX out, but the Central Electricity Generating Board, which owns the site and is an industrial partners in NIREX, is unlikely to give away one of the few possible sites for a dump over which NIREX already has control.

The site is well served by transport links and is already something of an eyesore, so countryside conservationists are unlikely to object to its use. Inevitably, however, local people accuse NIREX of putting convenience before safety and say a more remote site should have been chosen. NIREX itself remains - or claims to remain - serene, although five local authorities have united to fight its plan. The authorities are making strong representations to government ministers now that it is known that NIREX intends shortly to submit a planning application. NIREX says no site-specific safety criteria have yet been drawn up and that all indications are that the Elstow site is suitable.

Tim Beardsley

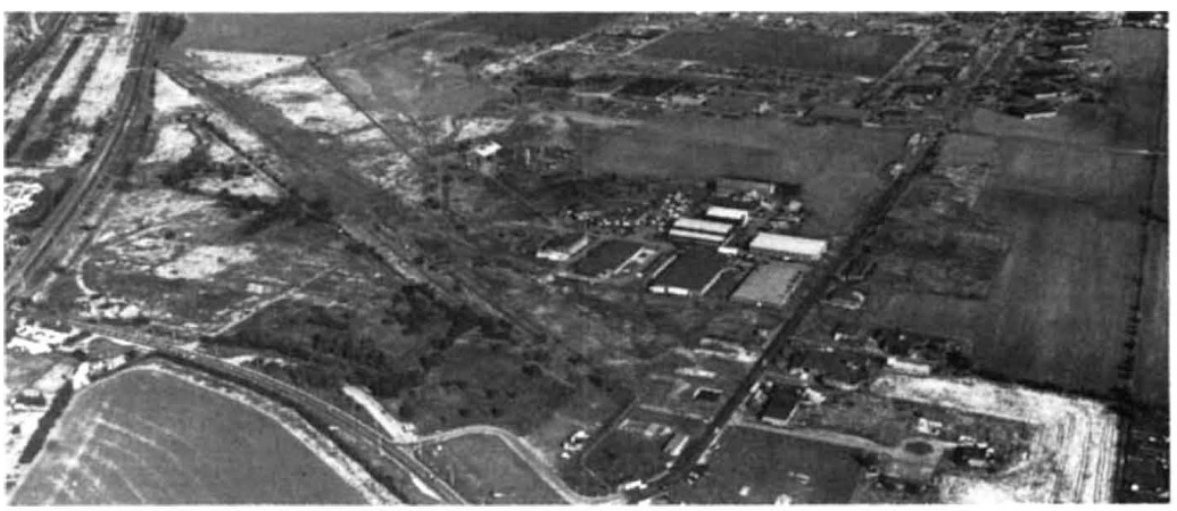

Looking north-east over the Elstow site
Soviet nuclear power

\section{Teething trouble persists}

THE Soviet nuclear power industry, which is running badly behind schedule, may have been granted a temporary respite by the death, last month, of the party leader, Mr Yurii Andropov. During the Central Committee plenum in June 1983, Mr Andropov gave his strong personal backing to the new energy programme involving the construction, over the next ten years, of 30 nuclear power stations, 12 of which will also provide district heating for cities in the European part of the Soviet Union.

On 8 February, Pravda published an editorial attacking delays in construction at many of these sites, including the fast breeder reactor at Beloyarsk. The tone of the article implies that one of $\mathrm{Mr}$ Andropov's drives against inefficiency and incompetence was planned for the nuclear construction industry, and that widespread upheavals and dismissals might be expected. Two days later, however, $\mathrm{Mr}$ Andropov died, and his successor, $\mathrm{Mr}$ Konstantin Chernenko, has so far concerned himself with international rather than domestic issues.

For some time there have been indications in the Soviet press that all is not well with the nuclear power programme. Conventionally, delays are blamed on late and insufficient supplies from the manufacturers of construction materials, equipment and generating machinery. The Pravda editorial repeats this line, urging severe economic penalties for breaches of contract by suppliers, with matching incentives for those of proven reliability.

Poor organization partly explains apparently contradictory progress reports. In January 1983, for example, Moscow Radio noted that construction of the nuclear power and district heating station in Gor'kii was two months ahead of schedule, but, two weeks later, reported that the whole project was being held up for lack of the safety-housing, already nearly a year overdue. The defaulting supplier was the Volgatsemmash production association in Tolyatti, but a few months later the most important of all suppliers to the nuclear industry, the Atommash association at Volgodonsk, came in for severe criticism in Pravda in terms which hinted that safety regulations were being ignored. A top Communist Party troubleshooter had to fly to Volgodonsk and, a few months later, a new high-level committee was set up to monitor safety in the nuclear industry.

Until recently delays in nuclear construc tion projects have received relatively little publicity, partly because the original target dates are not always public knowledge and partly because the installations most affected in the past few years have been 